\title{
Self Help Groups: An Effective Approach towards Women Empowerment
}

\section{OPEN ACCESS}

Manuscript ID:

ECO-2020-08033192

Volume: 8

Issue: 3

Month: June

Year: 2020

P-ISSN: 2319-961X

E-ISSN: 2582-0192

Received: 30.04 .2020

Accepted: 21.05.2020

Published: 01.06.2020

Citation:

Tigari;, Harish and

Aishwarya, R. "Self Help

Groups: An Effective

Approach towards Women

Empowerment." Shanlax

International Journal of

Economics, vol. 8, no. 3, 2020, pp. 47-55.

DOI:

https://doi.org/10.34293/

economics.v8i3.3192

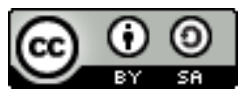

This work is licensed under a Creative Commons Attribution-ShareAlike 4.0 International License

\section{Harish Tigari}

Assistant Professor and Co-ordinator, Davan PG Studies, Davangere, Karnataka, India

D https://orcid.org/0000-0002-3770-6045

\section{R. Aishwarya}

PG Student, Davan PG Studies, Davangere, Karnataka, India

\section{Abstract}

In recent years, SHGs have become significant contributors to the generation of self-employment and source of livelihood. The Self-Help Group (SHG) is moving in the right direction in empowering women economically and socially and eradicating poverty in rural and urban areas. Selfemployment is necessary to eradicate the regional economic imbalance. Women's participation is necessary for the betterment of the economy. SHGs are one of the ways to increase the participation of women in economic activities. So, it empowers and creates women entrepreneurs. The study aims to provide empirical evidence of the contribution of SHGs to self-employment. For this purpose, the primary data were collected from the 30 members of SHGs by simple random sampling, and the data is collected through a structured questionnaire, Likert scale technique was used to measure the qualitative data. The estimated results show the self-employment opportunities created by SHGs. Keywords: Women Empowerment, Self-employment, Capital investment, Women Entrepreneurs

\section{Introduction}

Self Help Groups are the groups of poor and middle-class people, who provide mutual support to each other. They formed groups of people possess a similar sort of problems, similar consumptions patterns, who have socially and economically hostile and joined together to overcome the hindrances. Self-help groups are volunteers coming together with a group to solve their problems like lack of capital, inadequate income, etc. The self-help group is a platform to solve the problems of members of SHG and to make them self-reliant and empowered. According to NABARD, "SHG is a homogenous group of rural poor volunteers governed to save whatever the amount they can conveniently save out of their earning and mutually to contribute to a common fund to lend to the members for making their products and emergency consumption credit needs. The self-help group plays a significant role in rural poverty alleviation in India. It is noted that the Self-help groups have a vital role in developing the country's economy. The members of SHGs are actively engaged in saving money and receiving credit facility. SHG is one of the tools for achieving socioeconomic empowerment through the collective actions of SHG members. The SHG helps the women in becoming self-reliant and independent in building their confidence. It has been acknowledging that the goal of poverty eradication cannot be achieved without the empowerment of women. SHG not only provides an opportunity to get self-employed, but it also improves the socioeconomic conditions of rural women.

Self-help groups work under the principle of "for the people, by the people and of the people." The Self-help group is the brainchild of Gamelan Bank of Bangladesh, which was founded by Prof. Mohammed Yunar of Chittagong University in the year 1975. 
The SHG concept in India was initiated by NABARD during the year 1986-1987, but the real efforts were taken after 1991-92 with the linkage of SHG with banks. The SHGs were formed and developed by Mysore Resettlement and Development Authority (MYRADA) in 1984-85, and earlier, it was called Credit Management Groups. In 1987, NABARD sanctioned grant to MYRADA for building institutional capacity and to match the savings of the group. The first SHG was started in Dharmapuri district of Tamil Nadu in 1989, stated by Magilar Thittan in 1997 for the development of women in Tamil Nadu. On the success of SHG in Dharmapuri, it was further expanded to other districts of Tamil Nadu. Tamil Nadu is ranked 2nd in the country after Andra Pradesh. As of 31st March 2011, 9,51, 783 SHGs are operating in Tamil Nadu.

\section{Review of Literature}

(Nimisha and Dharmaraj Arumugam 2019)

In their study, "Impact of Self-Help Groups on self, social awareness and economic empowerment of women entrepreneurs of Coimbatore District" tried to understand the effectiveness of SHGs in the economic empowerment of women entrepreneurs in Coimbatore district and to study the demographic and socio-economic background of women entrepreneurs. The authors have discovered that the annual income of SHGs members has been raised along with the improvement of the economic status of the family. SHGs have given a great platform to exhibit their passion for starting their business enterprises rather than seeking employment opportunities.

(Prof. Mahadev .S. Terdal 2018) has conducted descriptive research on "Rural Development in India: A Role of a self-help group." The author has clearly explained the need and importance of SHG to rural women and the country as well. Further, the researcher explains the positive sides of SHGs like economic empowerment, social empowerment, political empowerment, psychological empowerment, etc. that play a predominant role in the development of women entrepreneurs, villages, and economic development of a country. The SHG reached the grass root and poor clients of a country. It is a significant indicator of an increased standard of living of members of SHGs.
(Nchumthung Murry and R Nakhara 2018) have conducted their research on "Study on profile and performance of women self-help groups in Nagaland." With the sole objective of studying the profile and performance of women self-help groups in Nagaland, the authors have identified effective functioning SHGs for detailed study. The researchers have tried to build a correlation between the tenure of the existence of SHG and performance score and the relationship between the literacy of the group leader and performance score. The study showed that the rotation of group leader, regular savings, repayment of loan, training awareness represented significant increases with the increase in tenure existence. The study also found that frequent meetings, level of record, group homogeneity reflected the increased performance of SHGs.

(Mrs. M.L Shailaja et al. 2016) has done empirical research on "Self-Help Groups- A complete understanding." The researchers have a clear description of the history and evolution of SHGs in India and their impacts. SHG reflects independence and empowerment. It allows the members of SHGs to save and borrow the funds according to their requirements. SHGs are the vehicles for the social and economic of a country. Authors have attempted to find the major challenges of SHGs like family discouragement, lack of information, lack of technical knowledge, psychological factors, and many more. The authors conclude that if the challenges are accomplished, and if the women are involved in SHGs, their economic and social status get empowered.

(M. Saravanan 2016) has worked on "The impact of Self-Help Groups on the Socio-Economic Development of Rural Households women in TamilA study." The author describes that self-help groups help rural women to acquire their powers for selfsupportive life, and he found that there is evidence of increased household income and standard of living. With the motto to alleviate rural poverty and increase employment opportunities, the researcher has done the groundwork to understand the benefits of SHGs for poor rural households. He reports that the implementation of SHGs has generated selfemployment opportunities for the rural poor, and the programs have helped many participants in 
improving their economic conditions. Thus, the SHG program plays a central role in the lives of the poor and middle class".

(Arjun Y Pangannavar 2014) in his paper titled "A Research Study on Development of Self-Help Groups in Belgaum district," it attempts to examine whether there are any development and growth of SHGs in Belgaum district during 2003-2010 and to find out the sustainability of their development. From the study it was analyzed that the government had made sincere efforts to bring more women to under the SHG movement to empower them politically, socially, psychologically, and economically. But the development of the SHG program was no popular in the district. The authors conclude saying that the development and popularity of the SHG program need effective efforts from all sides for the development in the district.

(Juno Gota 2014) has conducted an experimental study on "The Impact of Self- Help Groups Programs: Experimental and Survey Evidence from South India." The research aimed to provide evidence about the impact of SHGs programs on the economic and social impacts. The author estimates that there is a chance that the bias can rise due to the introduction of programs into targeted areas due to non-random program placement. The study evaluated and compared the impacts of SHGs on current and futures self-selected borrowers. The authors have given a brief note on internal and external loans and their policies and procedures.

(S. Thangamani and S.Muthuselvi 2014) conducted a study on "A study on women empowerment through self-help groups with the special reference to Mittupalyam Taluk in Coimbatore district." To find out the problems faced by members in SHGs and to analyze the income, expenditure, and savings pattern of self-help groups members, future strategies to suggest measure for the better management of SHGs, etc. It is understood from the analysis that the members of SHGs were highly satisfied, and it is found that socio-economic factors have been changed after joining the self-help groups. These also emerging issues that need to be addressed to make the role of women in the long run.

(Rachit Gupta and Dr. Shalini Agarwal) bought out evidence in their paper "A Study on Women Empowerment through Self-Help Groups with a special reference to Ghaziabad in Uttar Pradesh District." They aimed to study the economic empowerment, social empowerment, and personal empowerment of SHGs members and to study the income pattern of SHGs members. Here the researchers have done a comparative study on income and SHGs members before joining SHGs and after joining SHGs, and it was found that the economic, personal, and social conditions of members have been changed after joining SHGs and SHGs are restrengthening the human race.

\section{Objectives of the Study}

- To analyze the self-employment opportunities created by SHGs.

- To study the role of SHGs in economic empowerment.

\section{Problematisation}

SHGs are an opportunity for women to empower themselves and to build overall functional capacities. SHGs help poor and lower-income women in starting their own business so that they can create their source for income generation. The present study has been undertaken to check the self-employment generated with the help of SHGs. SHG is a small group of rural poor, who have voluntarily come forward to form a group for improvement of the social and economic status of the members.

\section{Methodology of the Study}

This is an analytical research paper; this paper concentrates on primary data and secondary data as well to gather information. The primary data is collected through a structured questionnaire. The selection of respondents is made on the simple ransom sampling. In this survey, the Likert scale technique was used to collect for questions like strongly agree, agree, neutral, disagree, and strongly disagree. Secondary data is collected through research journals, RBI publications, E-magazines, and internet sources. The secondary data collected may do define the issue and purpose of the study. However, the data is gathered, collected, and analyzed for the research. 


\section{Scope of the Study}

The rural and urban poor people are incapacitated due to various reasons, because most of them are socially, economically, and educationally backward, illiterate, with low motivation and poor economic base. Individually, a poor woman is not only weak in socio-economic terms but also lacks access to knowledge and information, which are the most important components of today's development process. However, in a group, they are empowered to overcome many of these shortcomings. This study is a micro-level study restricted to the Gutter colony of Harihar and limited only to the members of SKDRDP.

\section{Limitations of the Study}

- Due to the academic schedule, the researcher has less time to complete the task.

- The samples considered for the study is restricted to 30 only.

- The study considers the respondents of SKDRDP only.

- The geographical area covered is limited to the Gutter colony.

\section{Data Analysis and Interpretation}

Table 1: Demographic Profile of the respondents

\begin{tabular}{|l|c|c|l|c|c|}
\hline \multicolumn{1}{|c|}{ Age } & $\mathbf{F q}$ & $\mathbf{\%}$ & Marital Status & $\mathbf{F q}$ & $\mathbf{\%}$ \\
\hline 20-29 years & 04 & 6.77 & Married & 46 & 76.67 \\
\hline 30-39 years & 14 & 23.33 & Unmarried & 04 & 06.67 \\
\hline 40-49 years & 32 & 53.33 & Divorced & 10 & 16.66 \\
\hline 50 and above & 10 & 16.67 & Widow & - & - \\
\hline \multicolumn{1}{|c|}{ Total } & 60 & 100 & Total & 60 & 100 \\
\hline \multicolumn{1}{|c|}{ Education } & $\mathbf{F q}$ & $\mathbf{\%}$ & Family Size & $\mathbf{F q}$ & $\mathbf{\%}$ \\
\hline Illiterate & 06 & 10.00 & Below - 3 & 22 & 36.67 \\
\hline Higher Secondary & 30 & 50.00 & 4 & 18 & 30.00 \\
\hline PUC & 14 & 23.33 & 5 & 10 & 16.67 \\
\hline Graduates & 10 & 16.67 & 06 and Above & 10 & 16.67 \\
\hline \multicolumn{1}{|c|}{ Total } & 60 & 100 & Total & 60 & 100 \\
\hline Type of family & $\mathbf{F q}$ & $\mathbf{\%}$ & Business & $\mathbf{F q}$ & $\mathbf{\%}$ \\
\hline Joint family & 12 & 20 & Service & 16 & 27 \\
\hline Nuclear family & 48 & 80 & Manufacturing & 38 & 63 \\
\hline \multicolumn{1}{|c|}{ Total } & 60 & 100 & Both & 06 & 10 \\
\hline Source: Field survey & & & Total & 60 & 100 \\
\hline
\end{tabular}

Age: From the table, $6.67 \%$ of the respondents belong to the age group of $20-29$ years, $23.33 \%$ of the respondents belong to the age group of 30-39 years, $53.33 \%$ of the respondents belong to the age group of $40-49$ years \& remaining $16.67 \%$ of the respondents belong to age group of 50 years and above.

Marital Status: From the table, $76.67 \%$ of the respondents are married, $6.67 \%$ of the respondents unmarried, and the remaining $16.67 \%$ of the respondents are window. It reveals that SHGs are running and managed by women.

Education: From the table, $10 \%$ of the respondents are illiterate, $50 \%$ of the respondents have completed secondary education, $23.33 \%$ of the respondents have completed PU, and $16.67 \%$ of the respondents are graduates. It reveals that there is no compulsion of education to be a member of SHGs.

Family type: From the table, $20 \%$ of the respondents are in a joint family, and the remaining $80 \%$ of the respondents are in the nuclear family.

Nature of business: From the above table it is evident that out of 60 respondents, $27 \%$ of the respondents are in the service sectors, $63 \%$ of the respondents are in the manufacturing sector, and the remaining $10 \%$ of the respondents are in manufacturing as well as a service sector 
Table 2: Fact Sheet of SHG Members

\begin{tabular}{|c|c|c|c|c|c|}
\hline Purpose of loan & $\mathbf{F q}$ & $\%$ & Monthly income & $\mathbf{F q}$ & $\%$ \\
\hline Personal Expenses & 12 & 20 & Below RS. 5,000 & 08 & 13 \\
\hline Investment & 40 & 67 & RS. 5,000 to RS. 10,000 & 38 & 64 \\
\hline Cultural Events & 02 & 03 & RS. 10,000 to RS. 15,000 & 08 & 13 \\
\hline Others & 06 & 10 & RS. 15,000 and Above & 06 & 10 \\
\hline Total & 60 & 100 & Total & 60 & 100 \\
\hline Mode of awareness & $\mathbf{F q}$ & $\%$ & Non-Business activity & $\mathbf{F q}$ & $\%$ \\
\hline Self & 08 & 13 & Personal Expenses & 14 & 32 \\
\hline Family members & 12 & 20 & Cultural Events & - & - \\
\hline Friends and Relatives & 16 & 27 & Purchase of electronic & - & - \\
\hline Others & 24 & 40 & Others & 30 & 68 \\
\hline Total & 60 & 100 & Total & 44 & 100 \\
\hline Age of SHG & $\mathbf{F q}$ & $\%$ & Motives & $\mathbf{F q}$ & $\%$ \\
\hline Less than 2 years & 04 & 07 & Income & 06 & 10 \\
\hline 2 to 4 years & 08 & 13 & Government subsidies & 00 & - \\
\hline 4 to 6 years & 10 & 17 & Capital Investment & 36 & 60 \\
\hline 6 to 8 years & 26 & 43 & Social security & 04 & 7 \\
\hline 8 years and Above & 12 & 20 & Collective helps & 06 & 10 \\
\hline Total & 60 & 100 & Any others & 08 & 13 \\
\hline \multicolumn{3}{|l|}{ Source: Field survey } & Total & 60 & 100 \\
\hline
\end{tabular}

Purpose of availing loan: From the above table it is evident that out of 60 respondents, $20 \%$ of the respondents took the first loan to manage their expenses, $67 \%$ of the respondents took the first loan to make a capital investment, $3 \%$ of the respondents took for cultural events and remaining $10 \%$ of the respondents took to purchase households.

Monthly income.: It is evident from the above table, $13 \%$ of the respondents belong to the income category of below Rs.5,000, 64\% of the respondents belong to the income category of RS.5,000 to RS.10,000, $13 \%$ of the respondents belong to the income category of RS.10,000 to RS.15,000 and remaining $10 \%$ of the respondents belong to the income category of RS.15,000 and Above. It reveals that most members of SHG are from lower-middleincome class.

Introduction to SHG: From the above table it is evident that out of 60 respondents, $13 \%$ of the respondents joined SHG on their self-interest, $20 \%$ of the respondents were influenced by family members, $27 \%$ of the respondents were influenced by friends and relatives and remaining $40 \%$ of the respondents were influenced by the SP officers of SKDRDP.

Usage: From the above table it is evident that, out of 44 respondents, $32 \%$ of the respondents have utilized their business loan for personal usage and remaining $68 \%$ of the respondents have used their business loan for other activities like construction and repairs of the house, payments of school fees, etc.

Age of SHG: It is evident from the above table that, $7 \%$ of the respondents are in SHG since last 2 years, $13 \%$ of the respondents are in SHG since more than 2 years, but less than 4 years, $17 \%$ of the respondents are in the group since more than 4 years. Still, less than 6 years, $43 \%$ of the respondents are in a group since more than 6 years but less 8 years and remaining $20 \%$ of the respondents are in the SHG since the formation of SHG of their area.

Intension to join SHG: It is evident from the above table that, $10 \%$ of the respondents joined SHG to balance their regular income, $60 \%$ of the respondents joined SHG to make a capital investment, $7 \%$ of the respondents joined SHG to have social security, $10 \%$ of the respondents joined 
SHG for the collective helps and remaining $13 \%$ of maintain their expenses. the respondents joined SHG to clear debts and to

Table 3: SHGs Loan and Changing status

\begin{tabular}{|c|c|c|c|c|c|}
\hline Loan amount & $\mathbf{F q}$ & $\%$ & Purpose of loan & $\mathbf{F q}$ & $\%$ \\
\hline Below RS 20,000 & 28 & 47 & Initial Investment & 20 & 33 \\
\hline RS. 20,001 to RS. 50,000 & 16 & 27 & Purchase machinery & 04 & 07 \\
\hline RS. 50,001 to RS. $1,00,000$ & 02 & 03 & Working Capital & 20 & 33 \\
\hline RS. $1,00,001$ and Above & 14 & 23 & Additional Investments & 16 & 27 \\
\hline Total & 60 & 100 & Total & 60 & 100 \\
\hline Allocation of loan amount & $\mathbf{F q}$ & $\%$ & Changes in employment status & $\mathbf{F q}$ & $\%$ \\
\hline Allocated & 44 & 73 & Unemployment to self-employment & 10 & 17 \\
\hline Not allocated & 16 & 27 & Wage employment to self-employment & 06 & 10 \\
\hline \multirow[t]{3}{*}{ Total } & 60 & 100 & Expansion in employment & 06 & 10 \\
\hline & & & Expansion in business & 16 & 26 \\
\hline & & & No change in employment position & 22 & 37 \\
\hline & & & Total & 60 & 100 \\
\hline
\end{tabular}

Source: Field survey

Loan amount: From the above table, it is clear that out of 60 respondents, $47 \%$ of the respondents' loan amount was below RS 20,000, 27\% of the respondent's loan amount ranges between RS.20,001 to RS.50,000, 3\% of respondents took a loan from RS. $5,0,001$ to RS. $1,00,000,23 \%$ of respondents loan amount ranges from RS 1,00,001 and Above for the purchase of fertilizers and to install the required machinery.

Allocation of the loan amount: From the above survey, it is evident that out of 60 respondents, $73 \%$ of respondents have allocated their business loan amount for a different purpose,s and $27 \%$ of respondents have used the loan amount purely for the business. This reveals the members are using their business loan amount to non-business activities.

Allocation of the loan amount: From the above survey, it is evident that out of 60 respondents, $73 \%$ of respondents have allocated their business loan amount for different purposes and $27 \%$ of respondents have used the loan amount purely for the business. This reveals the members are using their business loan amount to non-business activities.

Purpose of loan: From the above table it is evident that out of 60 respondents, $33 \%$ of respondents took a loan to start a business, $7 \%$ of the respondents took machinery and technologies out of the loan, $33 \%$ of the respondents took loan their manage their day to day business expenses and remaining $27 \%$ of the respondents took a loan to make an additional investments to business.

Changes in employment status: From the above table it is evident that out of 60 respondents, $17 \%$ of the respondents have changed their employment position from unemployed to self-employed, $10 \%$ of the respondents changed their employment position from wage employment to self-employment, $10 \%$ of the respondents claim that there is an expansion in employment, $26 \%$ of the respondents claim that they have expanded their business and remaining 37\% of the respondents claim that there is no change in their employment position.

Table 4: Role of SHGs

\begin{tabular}{|c|c|c|c|c|c|c|c|c|c|c|c|}
\hline \multirow{2}{*}{\multicolumn{2}{|c|}{ Assumptions }} & \multicolumn{2}{|c|}{ SA } & \multicolumn{2}{|c|}{$\mathbf{A}$} & \multicolumn{2}{|c|}{$\mathbf{N}$} & \multicolumn{2}{|c|}{ D } & \multicolumn{2}{|c|}{ SD } \\
\hline & & FQ & $\%$ & FQ & $\%$ & FQ & $\%$ & FQ & $\%$ & FQ & $\%$ \\
\hline 1 & SHGs helps in self-development & 34 & 56 & 18 & 30 & 04 & 07 & 04 & 07 & 00 & 00 \\
\hline 2 & SHGs helps in empowerment & 34 & 57 & 18 & 30 & 04 & 07 & 02 & 03 & 02 & 03 \\
\hline 3 & Internal conflicts in SHGs & 00 & 00 & 30 & 50 & 04 & 07 & 06 & 10 & 20 & 33 \\
\hline
\end{tabular}




\begin{tabular}{|c|l|c|c|c|c|c|c|c|c|c|c|}
\hline 4 & Increasing social status & 12 & 20 & 30 & 50 & 06 & 10 & 06 & 10 & 06 & 10 \\
\hline 5 & SHGs is only for Business & 04 & 07 & 00 & 00 & 00 & 00 & 02 & 03 & 54 & 90 \\
\hline 6 & Improves financial conditions & 14 & 23 & 40 & 67 & 04 & 07 & 00 & 00 & 02 & 03 \\
\hline 7 & SHGs improves business skills & 26 & 43 & 22 & 37 & 02 & 03 & 02 & 03 & 08 & 14 \\
\hline 8 & Discharging family responsibilities & 30 & 50 & 22 & 37 & 06 & 10 & 00 & 00 & 02 & 03 \\
\hline 9 & Interest rates are less than banks & 50 & 84 & 08 & 13 & 02 & 3 & 00 & 00 & 00 & 00 \\
\hline 10 & Gaining management awareness & 26 & 44 & 14 & 23 & 12 & 20 & 02 & 03 & 06 & 10 \\
\hline 11 & Women prefer SHGs v/s finance institutions & 50 & 84 & 04 & 07 & 02 & 03 & 02 & 03 & 02 & 03 \\
\hline
\end{tabular}

Source: Field survey

Self-development: $56 \%$ of the respondents strongly agree, $30 \%$ of the respondents agree, $7 \%$ of the respondents claim neutral, and $7 \%$ of the respondents disagree with SHGs helps in selfdevelopment.

Self-empowerment: $57 \%$ of the respondents strongly agree, $30 \%$ of the respondents agree, $4 \%$ of the respondents claim neutral, $3 \%$ of the respondents disagree, and $3 \%$ of the respondents disagree with SHG helps in self-empowerment.

Internal conflicts: $30 \%$ of the respondents agree, $7 \%$ of the respondents claim neutral, $10 \%$ of the respondents disagree, and $33 \%$ of the respondents strongly disagree with internal conflicts that influence them to quit SHG.

Increase in social status: $20 \%$ of the respondents strongly agree, $50 \%$ of the respondents agree, $10 \%$ of the respondents claim neutral, $10 \%$ of the respondents disagree, and $10 \%$ of the respondents disagree with SHG benefits in increasing social benefits.

Business startups: $7 \%$ of the respondents strongly agree, $3 \%$ of the respondents disagree, and $90 \%$ of the respondents strongly disagree with SHG are meant only for start-ups.

Financial conditions: $23 \%$ of the respondents strongly agree, $67 \%$ of the respondents agree, $7 \%$ of the respondents claim neutral, and $3 \%$ of the respondents strongly disagree with SHGs helps in improving financial conditions.

Business skills: $43 \%$ of the respondents strongly disagree, $37 \%$ of the respondents agree, $3 \%$ of the respondents claim neutral, $3 \%$ of the respondents disagree, and $14 \%$ of the respondents strongly disagree with SHG helps in improving business skills.
Family responsibilities: $50 \%$ of the respondents strongly agree, $37 \%$ of the respondents agree, $10 \%$ of the respondents claim neutral, and $3 \%$ of the respondents strongly disagree with after being a member of SHG, you feel better to take responsibilities of family.

Rate of interest: $84 \%$ of the respondents strongly disagree; $13 \%$ of the respondents agree, and 3\% of the respondents claim neutral with the rate of interest of SHG is less than the rates nationalized and other banks.

Awareness about management: $44 \%$ of the respondents strongly agree, $23 \%$ of the respondents agree, $20 \%$ of the respondents claim neutral, $3 \%$ of the respondents disagree, and $10 \%$ of the respondents strongly disagree with the SHG helps in gaining awareness about management.

Preference of SHG over banks: $84 \%$ of the respondents strongly agree, $7 \%$ of the respondents agree, $3 \%$ of the respondents claim neutral, $3 \%$ of the respondents disagree, and $3 \%$ of the respondents strongly disagree with preference to take loans in SHGs than other banks.

\section{Findings of the Study}

- It is found $84 \%$ of the women prefer to join SHGs because of less interest rate, refundable amounts on the death of a spouse, and availability of loans at the doorstep.

- From the study, it is found that SHGs not only provide loans to the needy person, but they also help the women in enhancing their business and management skills through their training centers.

- From the research, it is revealed that the interest is less to members of SHG who have taken a loan on the training certificate issued by RUDEST.

- From the study, it is found that women with less 
income ranged between RS.5,000 to RS. 10,000 join SHG to manage their needs.

- It is proved that $73 \%$ of the respondents have diversified their business loan for cultural events, to purchase electronics, to manage expenses.

- SHG has not only empowered the members of SHG, but the SHG has also empowered the general public through the members of SHG.

- From the study, it was found that $63 \%$ of women are engaged in providing tailoring services, hotel services, Auto services, food processing services, and retail services.

- $86 \%$ of respondents have agreed that the SHG has helped them in self-development.

- $80 \%$ of the respondents have claimed that their financial conditions have improved after being a member of SHG.

- $83 \%$ of respondents prefer to take loans in SHG rather than nationalized banks, private banks, and other financial institutions.

- $60 \%$ of the respondents joined SHG to avail of the loan for making an initial investment in their business.

- Credit is facilitated only to those women who are between 18-59 years.

- On the death of the nominee of the SHG member, the availed loan amount is refunded.

\section{Suggestions}

- As there is no training center in the city, SHG members must go to another city to get trained. It is quite difficult for women to leave family and to stay in other cities.

- The head of the group should be changed on a timely basis so that members are motivated to work precisely. It allows everyone to understand the working procedures of SHG.

- For the growth and development of SHGs, members are required to conduct meetings regularly and discuss the issues.

\section{Conclusion}

A woman is the root of every family, which builds a better family tree. Enriching women in aspects like education, employment, and entrepreneurs add value to the social, political, and economic empowerment. SHGs are an opportunity for women to employ themselves, along with employing other people. Thus, SHG is an important tool that helps women to possess the power of self-supportive life. The study proves that there is a positive impact of SHG on poor and lower-income women. Steve Maraboli quoted that "The Empowerment of women is powerful beyond measure and beautiful beyond description." Women Empowerment is a tool often linked with feminism. Women empowerment refers to the expansion of political, social, education, gender, and economic soundness of women. Women's empowerment is widely accepted as an indication of economic development. Investing in women empowerment can bring colossal change in the poverty eradication, regional development, and economic development as well. In the recent report, MFI estimated that if an equal part of women is in the workforce, the GDP will increase by $27 \%$. From the Five-year plan (1974-1978) empowerment of women has been considered as the central issue. The Government has been implementing various plans and programs for the socio-economic development of women in the country. But, still, there is a spacious gap between goals articulated in plans and situational reality in India. The NGOs have given considerable grass-roots presence and deep insight to empower women physically, mentally, socially, politically, and economically.

\section{References}

Ahmed, S., et al. "Women's Political Participation and Changing Pattern of Leadership in Rural Areas of U.P." The Indian Journal of Political Science, vol. 69, no. 3, 2008, pp. 661-672.

Al-Ghamadi and Ahmed, S. "Leaders' Situational Control in the Public and Private Sectors in Saudi Arabia." Dissertation Abstract International, vol. 50, no. 12, 1990.

Baruah, B. "Role of Electronic Media in Empowering Rural Women Education of N.E. India." ABHIBYAKTI, vol. 1, 2013, pp. 23-26.

Chandrakavate, M.S. "SHGs Model of Microfinance: A Silent Movement towards Empowering Rural Women." Southern Economist, vol. 44, 2006, pp. 29-32.

Duflo, Esther. “Women's Empowerment and Economic Development." NBER Working Paper No. 17702, 2011. 
Goto, Juno. "The Impacts of Self-help Group Programs; Experimental and Survey Evidence from South India." Economics Bulletin, vol. 33, no. 4, 2013, pp. 2874-2889.

Gupta, Rachit and Shalini Agarwal. "A Study on Women Empowerment through Self-help Groups with Special Reference to Ghazibad in Uttar Pradesh District." International Journal for Research in Applied Science \& Engineering Technology, vol. 5, no. 6, 2017, pp. 1439-1444.

Kadam, R.N. "Empowerment of Women in India - An Attempt to Fill the Gender Gap (June, 2012)." International Journal of Scientific and Research Publications, vol. 2, no. 6, 2012.

Kishor, Sunita and Kamla Gupta. Gender Equality and Women"s Empowerment in India, National Family Health Survey (NFHS-3) India, 2005-06, International Institute for Population Sciences, 2009.

Manvar, H.A., et al. "Role of Self-help Groups in Women Empowerment and Health." International Journal of Current Microbiology and Applied Sciences, vol. 8, no. 4, 2019, pp. 31-38.

Murry, Nchumthung, and R. Nakhro. "Study on Profile and Performance of Women Self Help Groups in Nagaland." International Journal of Agriculture Sciences, vol. 10, no. 17, 2018, pp. 7074-7076.

Muttesha, and K.P. Ashwini. "A Study on Women Empowerment through Self Help Groups (An Empirical Study in Harihara, Davangere District)." IOSR Journal of Business and Management, vol. 21, no. 4, 2019, pp. 16-31.

Nandini, R. and N. Sudha. "A Study on Women Empowerment through Self-help Groups - With Special Reference to Ramanagar
District, Karnataka." BIMS International Journal of Social Science Research, vol. 1, no. 1, 2016, pp. 07-15.

Nimisha, M. and Dharmaraj Arumugam. "Impact of Self-help Groups on Self, Social Awareness and Economic Empowerment of Women Entrepreneurs of Coimbatore District." International Journal of Engineering and Advanced Technology, vol. 8, no. 5, 2019, pp. 1007-1014.

Pangannar, A.Y. "A Research Study on Development of Self-help Groups in Belgaum District." Pragati: Journal of Indian Economy, vol. 1, no. 1, 2014, pp. 61-76.

Rego, Paul A. "Women Entrepreneurship: Issues and Challenges." Journal of Development and Social Change, vol. 3, no. (3\&4), 2006.

Saravanan, M. "The Impact of Self-help Groups on the Socio-economic Development of Rural Household in Tamil Nadu." International Journal of Research - Granthaalatah, vol. 4, no. 7, 2016, pp. 22-31.

Sharma, Priyanka and A. Dhanalakshmi. "Determinants of Effectiveness of Women's Self-help Group - A Conceptual Study." IOSR Journal of Engineering, vol. 8, no. 11, 2018, pp. 63-66.

Thangamani, S. and S. Muthuselvi. "A Study on Women Empowerment through Self-help Groups with Self Reference to Mettupalayam Taluk in Coimbatore District." IOSR Journal of Business and Management, vol. 8, no. 6, 2013, pp. 17-24.

Terdal, M.S. "Rural Development in India: A Role of Self-help Group." International Journal of Advanced Research in Education \& Technology, vol. 5, no. 3, 2018, pp. 32-34.

\section{Author Details}

Harish Tigari, Assistant Professor and Co-ordinator, Davan PG Studies, Davangere, Karnataka, India.

Email ID: hstkplr148@gmail.com.

Ms. R. Aishwarya, Davan PG Studies, Davangere, Karnataka, India. 